Article

\title{
Identification of Variables that Predict Teachers' Attitudes toward ICT in Higher Education for Teaching and Research: A Study with Regression
}

\author{
Francisco D. Guillén-Gámez ${ }^{1, *(\mathbb{D})}$ and María J. Mayorga-Fernández ${ }^{2}$ (D) \\ 1 Department of Didactics and School Organization, University of Almería, 04120 Almería, Spain \\ 2 Department of Didactics and School Organization, University of Malaga, 29071 Málaga, Spain; \\ mjmayorga@uma.es \\ * Correspondence: dguillen@ual.es
}

Received: 27 January 2020; Accepted: 10 February 2020; Published: 11 February 2020

check for updates

\begin{abstract}
The aim of this research is to analyse the attitudes towards information and communication technologies (ICT) of higher education teachers from an affective, cognitive and behavioural model for teaching and research. It also aimed to explore different factors that can predict such attitudes. A non-experimental study was proposed using a survey technique and descriptive and inferential analyses were carried out using a multiple linear regression model (MLR). In total, the sample was formed by 867 university professors from Spain belonging to different areas of knowledge. The results show that these teachers have a medium total attitudinal level, so the lowest attitudes have been represented by the behavioural ones, followed by the affective ones. Regarding the predictor variables, variables that can predict such attitudes were found to be age, participation in projects, gender and teaching in face-to-face and/or online universities (ordered from highest to lowest priority).
\end{abstract}

Keywords: higher education; teachers; ICT; attitudes; new technologies

\section{Introduction}

In recent decades, education has undergone a substantial transformation due to the rise of information and communication technologies (ICT). Such technology plays an important role in the lives of people, both academically and professionally [1]. In line with these transformations, it is necessary to place a greater emphasis on pedagogical digital competence when training teachers so that education professionals can make the most of technological advances in order to design, innovate and integrate optimal teaching-learning processes that are enriching for students [2-4].

In this context, the Horizon 2017 report [5] points out that innovation in higher education (particularly in universities) has been increased, to a large extent, by the current technological developments, which have transformed traditional methodologies. These technologies have become essential for both teachers and researchers when designing innovative solutions to real world problems. Despite this, different studies emphasise that universities continue to use methodologies considered traditional, such as textbooks, blackboard and chalk, and on a few occasions, digital whiteboards $[6,7]$.

Some studies have shown that ICT can make a great contribution to improving student learning $[8,9]$. Many of these scientific investigations have focused on finding out the effects of ICT on student performance $[10,11]$. However, few studies have focused on identifying the attitudes of teachers towards ICT, specifically in higher education in an international context and very few in the Spanish context [12-15].

Nowadays, with the increase of 2.0 tools, the successful integration of ICT at any educational stage requires that university professors have a correct attitude towards technology since this can 
affect the teaching and learning process of their students $[13,16]$. On the contrary, if teachers stress that their confidence in the usefulness of technology is low or negative, their integration into the classroom will hardly be optimal. On the other hand, teachers with a positive attitude are more likely to use technology efficiently in their teaching [14,17-19].

Therefore, the general purpose of this study is to analyse attitudes of higher education teachers towards ICT and consequently to explore different factors that can predict such attitudes.

\section{Theoretical Framework}

\subsection{Approach to the Concept of Attitude towards ICT and Its Structure}

For Semerci and Aydin [20], attitude can be defined as an element that guides the behaviour of an individual in coherence with their feelings and thoughts. Moreover, attitude has come to be considered as the level of positive or negative effect associated with a particular object or belief [21].

Cai et al. [22] affirm that attitude towards ICT can be considered as a multifaceted construct composed of different elements, such as the anxiety or comfort that the teacher feels when using technology (personal emotions); the motivation that teachers have in the enjoyment of using 2.0 resources with their students (personal interest); the beliefs that you have acquired throughout your life about the usefulness of these technological devices; or the self-efficacy of teachers on the use of them. Spanos and Sofos [23] classify attitudes towards ICT into three categories: Anxiety, enjoyment and self-confidence. Cai et al. [22], on the other hand, identify four categories: Affection, belief, self-efficacy and mixed.

In recent decades, this multidimensionality character of attitudes has been rid of contention in the scientific literature and various different dimensions have been established [24-28]. Therefore, a unit score in attitude cannot be established [28].

A possible classification has been established by Ostrom [29], Norman [30], Breckler [31], Maio et al. [32], who consider that attitudes are shaped by three dimensions: Affective, cognitive and behavioural (ACB Model). Liaw [33] states that attitudes must be divided into this ACB model in order to know the attitudes of users about online technology. Moreover, authors such as Liaw and Huang [34] and Abdullah et al. [35] state that if teachers have more positive affective, cognitive and behavioural attitudes about technology such as virtual learning platforms (LMS), then they would have a greater intention to integrate this technology in the teaching and learning process with students. Therefore, the incorporation of technologies in teaching is conditioned by the attitudes of the teachers' ACB model and the expectations they have regarding the use of emerging technologies $[36,37]$. Taking into account that society is progressing rapidly and technology is constantly changing and transforming, it is an essential requirement to continue analysing the attitudes of teachers on how to improve the integration of technologies in education.

From the ACB model, affective dimension refers to the feelings and emotions that make an individual react and allow them to decide what attitude to take towards the current situation [38,39]; cognitive dimension is based on the beliefs and values that a person possesses, which makes reference to what they have learned in their life experience [40-42]; and behavioural dimension is focused on the behaviour and intention that an individual has who is faced with a certain situation and must act [43].

\subsection{Attitudes towards ICT: Related Studies}

In the scientific literature, attitudes towards ICT have been investigated in different populations (educational stages), as well as from different approaches. Taking into account the ACB model used in this study, the related works are as follows:

Ankiewicz et al. [44] created an instrument called ATP focused on affective and cognitive attitudes. The objective of the article was to compare the attitudes of 414 university students regarding gender. The results did not indicate gender differences towards the technological process. However, this instrument was focused on university students and not on teachers of higher education; in addition, 
it did not include the behavioural dimension. Along similar lines, Shaft et al. [45] developed an instrument based on the ACB model. However, for the creation and verification of its psychometric properties, 176 university students were used. Therefore, this instrument was not focused on measuring the attitudes of teachers of higher education. Bakr [46] measured the attitudes of 118 professors based on the ACB model; however, the sample used was teachers in secondary education and not in higher education. In addition, the author determined that there were no significant differences in terms of gender and teaching experience.

Reviewing the studies that have analysed and compared the dimensions of the ACB model, we found out that few investigations have been carried out. Judi et al. [47] analysed the attitudes of 39 secondary school teachers in a rural area of Malaysia. While the results showed that the teaching staff had positive attitudes toward ICT, they had more positive attitudes in the cognitive factor regarding the behavioural factor, while the affective dimension had the lowest score. In addition, in this research, significant data regarding the gender and age of the participants were not found. Abdullah et al. [48] found similar results in their study; affective dimension towards ICT seemed to be lower than behavioural and cognitive attitudes. In contrast, Wahyuni [49] found different results. The attitudes towards use of technologies were more favourable in the affective dimension than in the behavioural dimension. Jegede et al. [12] obtained similar results. In their study, a total of 467 teachers of higher education were asked about whether their affective, cognitive and behavioural attitudes affected the development of their technological competences. The data showed that it only influenced significantly the affective dimension.

On the other hand, we wanted to know from the literature about those significant variables that help predict attitudes towards technology through multiple regressions. Onasanya et al. [50] analysed the possible factors that significantly influence the attitudes of 150 higher education teachers. The results showed that gender did not exert effects on their attitudes about the integration of technological tools or in the learning of their students, nor in scientific research. However, there were significant influences regarding work experience, since the less experienced teachers had, the more favourable attitudes towards the use of ICT they manifest. These results are corroborated with those obtained by Kpolovie and Awusaku [15], Olafare et al. [51] and Semerci and Aydin [20]. Nonetheless, according to Alshammari et al. [18], both variables, age and teaching experience, influenced the attitude toward technologies; younger teachers with less work experience were more favourable. Despite this influence, they found that university teachers had a good attitude towards mobile technologies.

Taking into account how attitudes towards ICT have been previously investigated, few investigations have focused on the ACB Model (affective, cognitive and behavioural) in higher education. This is one of the main contributions that the authors make to the scientific field: The study of attitudes towards technology in relation to the ACB model. In addition, few studies have been carried out that jointly analyse attitudes towards technology in teaching and research fields of higher education teachers, taking a step forward in this type of research. In addition, few studies focus on finding out other factors that can significantly affect attitudes towards technology in higher education contexts (through regression models). Instead, previous studies focus on the gender and teaching experience of the teaching staff, and not for example on the number of innovations and research projects in which they collaborate, research stays in other universities, type of education (face-to-face/online) that they employ, type of university (public/private) in which they work, among other things. Therefore, the field of study of these predictive variables has been broadened since including these variables makes the present research have a more solid base.

Therefore, the aim is to find out the affective, cognitive and behavioural attitudes (ACB model) of higher education teachers towards ICT regarding teaching and research. Secondly, it aims to predict variables that may significantly influence attitudes towards ICT. 


\section{Method}

\subsection{Design}

For the purpose of this study, the authors have used an ex post facto non-experimental methodology through online surveys [52]. Descriptive and inferential analyses were also carried out in order to detect those variables that are significant regarding the development of teachers' attitudes in their teaching with their students and scientific research.

\subsection{Participants}

The target population of the present study is higher education teachers in Spain, of which there are currently 120,383 [53]. Email was used to contact 12,538 teachers who belonged to different Spanish universities distributed throughout the country; 1206 teachers responded. Once the data collection was completed, a preliminary treatment of the data was carried out in order to debug and eliminate those cases that the participants had left blank in the questionnaire. The final sample size was exactly 867 higher education teachers from Spain. Regarding the confidentiality of the answers of the participants, the survey was filled out anonymously, guaranteeing the privacy of their data. They were also informed of the purposes of the investigation.

The participating teachers were selected through an intentionally non-probabilistic sampling process. The distribution by areas of the teaching staff was: Social-legal sciences $(\mathrm{N}=400)$; science and engineering-architecture $(\mathrm{N}=183)$; health sciences $(\mathrm{N}=173)$; and art-humanities $(\mathrm{N}=111)$. Regarding the sociodemographic characteristics, it can be seen that 415 participants were female, with an age range between 24 and 69 years $(M=46.56 ; \pm 9.55)$ and 452 were male, with an age range between 24 and 73 years $(M=48.47 ; \pm 10.34)$. Finally, the sample was described from the academic profile of the teaching staff, $14.5 \%$ of the sample had four years or less of university teaching experience, $21 \%$ between five and ten years and $20.6 \%$ between 11 and 19 years, while the remaining $43.9 \%$ had 20 years or more of experience as a university professor.

The sample of this study can be considered representative of the population of higher education teachers in Spain as it is configured by participants belonging to the different areas of knowledge that articulate the Spanish university education system. In addition, the sample was balanced in frequencies with respect to gender, as well as in years of experience.

\subsection{Instrument Used to Measure Attitudes towards ICT}

In the present study, an adaptation of the instrument created by Romero et al. [54] was used which consisted of measuring attitudes towards technology. The original instrument was composed of 18 items classified into three dimensions: Affective, cognitive and behavioral attitudes to teaching; affective attitudes to research and cognitive attitudes to research, but not behavioral attitudes to research. In this study, the adaptation of the instrument was approached from the ACB model perspective: Affective attitudes to teaching and investigation, cognitive attitudes to teaching and research, and behavioral attitudes to teaching and research. The original instrument was written in Spanish, so the sample of participants had no problem in understanding and responding to the items.

The response mode consisted of a Likert scale of five points for each item, where value 1 was related to "totally disagree" and value 5 to "totally agree". The adaptation of the instrument was formed by a total of 24 items classified in the three dimensions of the ACB model.

The affective dimension was composed of eight items, four of which related to teaching (e.g., I feel sure of myself when using ICT in the classroom) and the other four items related to research (e.g., I have to use computer programmes for data processing when I carry out an investigation). The maximum score to reach in this dimension was 40 points. The cognitive dimension was composed of eight items, four of which related to teaching (e.g., I feel that my students have a better command of ICT resources than I do) and the other four items related to research (e.g., I believe that internet access favours an interconnection between the scientific community and the updating of knowledge). The maximum 
score to reach in this dimension was 40 points. The behavioural dimension was composed of a total of eight items, four of which related to teaching (e.g., ICT plays a key role in the planning of my teaching) and the other four items related to research (e.g., I keep my profile updated as a researcher in social networks). The maximum score to reach in this dimension was 40 points. The total maximum score of the instrument, with the sum of the three dimensions, was 120 points.

The reliability of the instrument was analysed according to each one of the dimensions of the instrument, focused on the ACB model. For this, Cronbach's Alpha was used. The coefficient reached in the total dimension was really good $(\alpha=0.90)$. Particularly, the coefficient of each dimension of the instrument yielded a correct reliability for this type of study: Affective dimension, $\alpha=0.71$; cognitive dimension, $\alpha=0.76$; behavioural dimension, $\alpha=0.85$.

To verify the validity of the instrument, an exploratory factor analysis was performed, in which the KMO values were adequate (0.921), as well as the significance of the model measured through Bartlett's sphericity $(p<0.05)$. The theoretical model constructed explained $52.10 \%$ of the total true variance of the participants' scores. It implies that the three dimensions of the ACB model are stable and explain enough true variance.

Table 1 shows the classification of variables used in the study. Those with the term DV are the dependent variables of the present study. The rest of the variables in the table are the independent variables (IV) which are going to be used in the regression models.

Table 1. Definition of variables.

\begin{tabular}{cc}
\hline Short Name & Description \\
\hline Act_total & Total attitude towards ICT of university teaching staff (DV) \\
Act_affective & Affective attitudes towards the ICT of the university teaching staff (DV) \\
Act_cognitive & Cognitive attitudes towards ICT of university teaching staff (DV) \\
Act_behavioral & Behavioral attitudes towards ICT of university teaching staff (DV) \\
Age & Age of the participants \\
Gender & Gender of the university faculty (nominal) \\
Stays & Total number of national and international research stays (ordinal) \\
Experience & No. of years of university teaching experience (ordinal) \\
Projects & No. teaching research and innovation projects (ordinal) \\
Postgraduate & No. of postgraduates studied and finished (ordinal) \\
Sexennium & Possess a research sexennium/do not possess it (nominal) \\
PhD & Have the title of PhD/do not have the title of PhD (nominal) \\
Teaching & Teaching face-to-face/online (nominal) \\
University & Type of University: Private/public (nominal) \\
\hline
\end{tabular}

Source: Own elaboration.

\subsection{Analysis of Data}

Once the study was designed and the participants' data were collected, three types of analysis were used, which are described below.

(1) First, an exploratory descriptive analysis of the attitudinal level was carried out in each dimension (ACB model).

(2) Second, different regression models were used in order to determine which variables are predictive in the variables dependent on the ACB model. For the analyses, the least squares method was used, as well as the "forward" method, in order to show only those significant variables among all the others introduced in the model. In addition, the assumptions that are necessary to make this type of inferential technique were checked. 


\section{Results}

The results section is divided into two sections: The first describes the attitudes of the teaching staff in each dimension of the ACB model; and the second section presents the results obtained through the regression models.

\subsection{Exploratory Descriptive Analysis of the Different Dimensions of the Instrument}

According to the affective attitudes towards teaching, it can be seen in Table 2 that the teaching staff has a positive predisposition toward the integration of ICT, since all the items obtain a high average score. However, it is noteworthy that the item related to "I am uncomfortable using a methodology based on ICT to assess students" also has a high score as a negative item. This indicates that this faculty usually does not use 2.0 tools related to evaluation.

The items focused on the affective attitudes towards ICT in the field of research were stated in a positive sense, with all scores obtaining above the average. Particularly highlighted items include "I feel burdened having to use computer programmes for the treatment of data when conducting research" which obtained an $\mathrm{M}=3.93 \pm 1.27$, and "It bothers me to have to update my academic profile," which received the lowest score $(\mathrm{M}=2.95 \pm 1.27)$. This indicates that the teaching staff has a certain positive predisposition towards that update.

Table 2. Affective attitudes towards information and communication technologies (ICT) in teaching and research.

\begin{tabular}{|c|c|c|c|}
\hline & $\mathbf{M}$ & Me & Sd \\
\hline I like that my methodology is based on the transversal use of ICT & 3.40 & 3.00 & 1.19 \\
\hline It bothers me to use a methodology based on ICT to evaluate the students & 3.68 & 4.00 & 1.31 \\
\hline I feel confident in myself when using ICT in the classroom & 3.81 & 4.00 & 1.12 \\
\hline I am interested in knowing new ICT tools that I can use in the classroom & 3.94 & 4.00 & 1.09 \\
\hline $\begin{array}{l}\text { I do not like to access databases and web browsers because I find it difficult to } \\
\text { manage the volume of information }\end{array}$ & 3.84 & 4.00 & 1.24 \\
\hline It bothers me to have to update my academic profile & 2.95 & 3.00 & 1.38 \\
\hline $\begin{array}{l}\text { I dislike having to dedicate my time to divulge research activities through social } \\
\text { networks }\end{array}$ & 3.13 & 3.00 & 1.36 \\
\hline $\begin{array}{l}\text { I feel burdened having to use computer software for the treatment of data when } \\
\text { conducting research }\end{array}$ & 3.93 & 4.00 & 1.27 \\
\hline
\end{tabular}

Source: Own elaboration.

Table 3 shows the items related to cognitive attitudes towards ICT. As can be seen in this table, all the items in this dimension for both teaching and research have a high-average rating, although the items related to teaching have a slightly lower score than those of research. It is noteworthy that the most valued item in teaching is related to the importance of using ICT in the teaching-learning process, which has been specifically employed in a transversal way $(\mathrm{M}=4.28 ; \pm 0.87)$. In contrast, the least valued item refers to the belief that ICT favours putting into practice a more innovative methodology and evaluation $(\mathrm{M}=3.54 ; \pm 1.18)$. Regarding research, within this dimension, it can be noted that all the average scores exceed four points. The most valued item is "I consider that internet access favours an interconnection between the scientific community and the updating of knowledge" $(\mathrm{M}=4.51$; \pm 0.75 ), while the least valued is related to the usefulness of ICT for quickly disclosing the results of an investigation $(\mathrm{M}=4.08 ; \pm 1.04)$.

The behavioural attitudes towards ICT are analysed in Table 4. In this dimension, when considering teaching, university teachers value above all the usefulness of ICT for interacting with their students $(\mathrm{M}=3.84 ; \pm 1.14)$, considering that ICT is a part of their day-to-day in the classroom $(\mathrm{M}=3.79 ; \pm 1.24)$. The least valued item is related to the role played by ICT in teaching planning $(\mathrm{M}=3.27 ; \pm 1.21)$. Regarding research, within the behavioural attitudes dimension, the faculty participating in the study more positively assessed the usefulness of ICT to stay informed of academic innovations in their field 
of research $(\mathrm{M}=3.70 ; \pm 1.18)$. In contrast, the least valued item referred to the update of one's profile as a researcher in the social networks of said faculty $(\mathrm{M}=2.98 ; \pm 1.36)$.

Table 3. Cognitive attitudes towards ICT in teaching and research.

\begin{tabular}{|c|c|c|c|}
\hline & $\mathbf{M}$ & Me & Sd \\
\hline I feel that my students dominate ICT resources more than I do. & 3.26 & 3.00 & 1.32 \\
\hline $\begin{array}{c}\text { I believe that ICT are important in the teaching-learning process and should be } \\
\text { worked in a transversal manner }\end{array}$ & 4.28 & 4.50 & 0.87 \\
\hline $\begin{array}{l}\text { I believe that ICT is helping me to have a more innovative teaching and evaluation } \\
\text { methodology }\end{array}$ & 3.54 & 4.00 & 1.18 \\
\hline I believe that ICT facilitates me to be updating in my field of knowledge & 4.06 & 4.00 & 1.03 \\
\hline I think the use of software for data processing in my research work is important & 4.27 & 5.00 & .99 \\
\hline $\begin{array}{l}\text { I believe that Internet access favors the interconnection between the scientific } \\
\text { community and the updating of knowledge }\end{array}$ & 4.51 & 5.00 & 0.75 \\
\hline I believe that ICT allows me to disseminate the results of my research more quickly & 4.08 & 4.00 & 1.04 \\
\hline $\begin{array}{l}\text { I believe that access to the Internet gives me the opportunity to learn about new } \\
\text { resources that facilitate my work as a researcher }\end{array}$ & 4.35 & 5.00 & 0.85 \\
\hline
\end{tabular}

Source: Own elaboration.

Table 4. Behavioural attitudes towards ICT in teaching and research.

\begin{tabular}{|c|c|c|c|}
\hline & $\mathbf{M}$ & Me & Sd \\
\hline ICT is part of my day to day in the classroom & 3.79 & 4.00 & 1.24 \\
\hline ICT play a priority role in the planning of my teaching & 3.27 & 3.00 & 1.21 \\
\hline My way of interacting with students is favored thanks to the use I make of ICT & 3.84 & 4.00 & 1.14 \\
\hline In my classes, I encourage the use of ICT in my students & 3.66 & 4.00 & 1.17 \\
\hline I do ICT training courses that help me improve my skills as a researcher & 3.20 & 3.00 & 1.38 \\
\hline I keep my profile updated as a researcher in social networks & 2.98 & 3.00 & 1.36 \\
\hline I use ICT to maintain a fluent communication with other researchers & 3.65 & 4.00 & 1.24 \\
\hline $\begin{array}{l}\text { I keep informed, through the TIC, of the academic novelties that are presented in the } \\
\text { field of work in which I investigate }\end{array}$ & 3.70 & 4.00 & 1.18 \\
\hline
\end{tabular}

Source: Own elaboration.

Table 5 shows the level of total attitudes measured by the instrument, as well as the level of attitudes for each of the dimensions analysed. It can be seen that the lowest scores are obtained by the behavioural attitudes $(M=28.12, \pm 6.98)$, followed by the affective attitudes $(M=28.69 ; \pm 5.73)$, obtaining in both of them a total low level of behavioural and affective attitudes. On the other hand, cognitive attitudes obtained a mean total score of $\mathrm{M}=32.36 ; \pm 4.98$. Regarding the level of total attitude towards ICT, it can be said that it is medium $(\mathrm{M}=89.39 ; \pm 15.42)$ compared to the maximum 120 points to be reached.

Table 5. Descriptive nature by each dimension of the instrument.

\begin{tabular}{cccc}
\hline & M & Me & Sd \\
\hline Affective attitudes (40 points) & 28.69 & 29.00 & 5.73 \\
Cognitive attitudes (40 points) & 32.36 & 33.00 & 4.98 \\
Behavioral attitudes (40 points) & 28.12 & 29.00 & 6.98 \\
Total Attitude (120 points) & 89.39 & 90.00 & 15.42 \\
\hline
\end{tabular}

Source: Own elaboration.

\subsection{Identification of Significant Factors in the Attitude of Teachers towards ICT}

For the prediction, four multiple linear regressions (MLR) have been used: The first regression is focused on the total attitudes towards the ICT, which include the summation all the items of the three dimensions of the instrument (ACB model). The following regressions are focused on the specific attitudes in each dimension of the instrument, each dimension encompassing the sum of their respective items. 
The variables used in each MLR are specified in Table 1, taking into account that the following variables have been recoded as dummy variables: Gender (male 0; female 1), possession of a research sexennium (no 0 ; yes 1 ), possession of a $\mathrm{PhD}$ degree (no 0 ; yes 1 ), type of education (face-to-face 0 ; online 1), type of university (private 0 ; public 1 ).

\subsubsection{Regression: Total Attitude towards ICT in Teaching and Research}

This first model was focused on knowing the total attitudes towards ICT of university teaching staff (ACB model as a whole). In the first place, the assumptions of normality, independence and multicollinearity of the residues were verified. Figure 1 shows the non-violation of these assumptions. In addition, the independence of the residues was verified through the Durbin-Watson statistic (D.W. = 1.83), this value being within the allowed threshold [55]. The last case tested was multicollinearity through tolerance and inflation coefficients (VIF) (Table 6). The coefficients found are within the allowed threshold (for tolerance values 0.6 , and for inflation values less than 10 ) $[56,57]$.
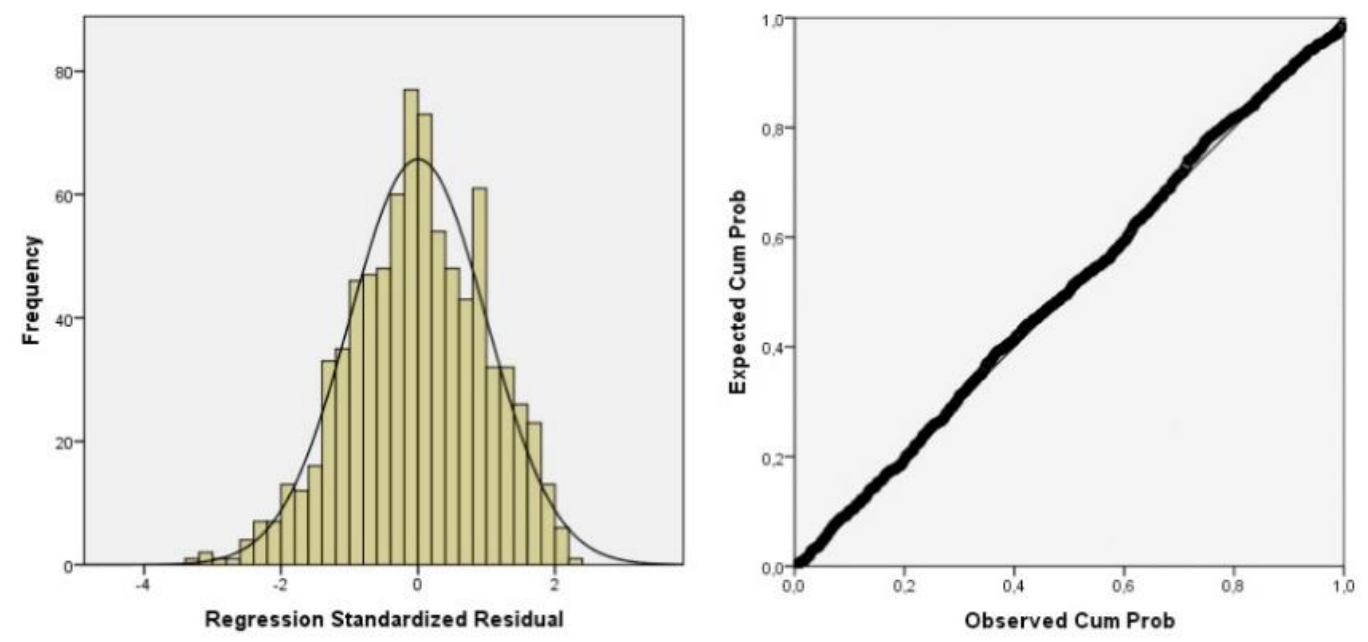

Figure 1. Assumptions of normality, independence and multicollinearity.

Table 6. Factor weights in the total attitudes regression model.

\begin{tabular}{cccccc}
\hline & Standardized Coefficients $\boldsymbol{\beta}$ & $\boldsymbol{t}$ & Sig. & Tolerance & VIF \\
\hline Constant & 103.096 & 35.987 & 0.001 & & \\
Age & -0.146 & -4.237 & 0.001 & 0.979 & 1.021 \\
N Projects & 0.112 & 3.265 & 0.001 & 0.990 & 1.010 \\
N Stays & 0.027 & 0.784 & 0.433 & 0.952 & 1.051 \\
Experience & 0.050 & 0.817 & 0.414 & 0.314 & 3.185 \\
N Postgraduate & 0.033 & 0.932 & 0.352 & 0.907 & 1.102 \\
Gender & -0.092 & -2.674 & 0.008 & 0.986 & 1.015 \\
Sexennium & 0.048 & 1.246 & 0.213 & 0.791 & 1.265 \\
PhD & -0.020 & -0.537 & 0.592 & 0.853 & 1.173 \\
Teaching & -0.111 & -3.226 & 0.001 & 0.988 & 1.012 \\
University & 0.004 & 0.097 & 0.923 & 0.758 & 1.319 \\
\hline
\end{tabular}

Source: Own elaboration.

This regression model was significant, $F(4,817)=10.676 ; p<0.05$; adjusted $\mathrm{R}^{2}=0.045$. In this equation line, only four variables were significant predictors: Age $(t=-4.237 ; p<0.05)$, belong to research/innovation projects $(t=3.265 ; p<0.05)$, gender $(t=-2.674 ; p<0.05)$ and the type of teaching $(t=-3.226 ; p<0.05)$, were significant variables, three of them having negative weights and only belonging to projects of a positive weight. The regression equation is formed by the constant and its corresponding explanatory variables: 


$$
Y_{0}=103.096-0.146 \text { Age }+0.112 \text { Projects }-0.092 \text { Gender }-0.111 \text { Teaching }
$$

4.2.2. Regression: Affective Attitudes towards ICT in Teaching and Research

The graphs of normality of the residues and their independence evidenced the normality of the model (D.W. $=1.98)$. The coefficients of non-collinearity of the variables are observed in Table 7 . This regression line was significant, $F(4,841)=17.167 ; p<0.05$; adjusted $\mathrm{R}^{2}=0.037$. For the affective dimension, only two variables were predictors in this equation line: Gender $(t=-5.018 ; p<0.05)$ and age $(t=-3.500 ; p<0.05)$. The equation is as follows, taking into account the standardized coefficients:

$$
Y_{0}=32.842-0.119 \text { Age }-0.170 \text { Gender }
$$

Table 7. Factorial weights in the affective attitudes regression model.

\begin{tabular}{cccccc}
\hline & Standardized Coefficients $\boldsymbol{\beta}$ & $\boldsymbol{t}$ & Sig. & Tolerance & VIF \\
\hline Constant & 32.842 & 33.629 & 0.001 & & \\
Age & -0.119 & -3.500 & 0.001 & 0.991 & 1.010 \\
N Projects & 0.014 & 0.411 & 0.681 & 0.991 & 1.009 \\
N Stays & -0.015 & -0.438 & 0.662 & 0.973 & 1.028 \\
Experience & 0.071 & 1.175 & 0.240 & 0.313 & 3.200 \\
N Postgraduate & 0.035 & 0.981 & 0.327 & 0.912 & 1.097 \\
Gender & -0.170 & -5.018 & 0.000 & 0.991 & 1.010 \\
Sexennium & 0.022 & 0.583 & 0.560 & 0.816 & 1.225 \\
PhD & -0.063 & -1.778 & 0.076 & 0.907 & 1.103 \\
Teaching & -0.057 & -1.693 & 0.091 & 0.988 & 1.012 \\
University & 0.014 & 0.408 & 0.683 & 0.977 & 1.023 \\
\hline \multicolumn{2}{c}{ Source: Own elaboration. } \\
\end{tabular}

\subsubsection{Regression: Cognitive Attitudes towards ICT in Teaching and Research}

Normality parameters were complied with in tolerance, VIF and Durbin-Watson (D.W. $=1.78$ ). This model was significant, $F(3,842)=12.524 ; p<0.05$, adjusted $R^{2}=0.039$. For the cognitive dimension, only three variables were predictive in teachers' attitudes; Table 8 shows their standardized coefficients: Age $(t=-5.243 ; p<0.05)$, gender $(t=-2.004 ; p<0.05)$ and number of research/innovation projects $(t=3.128 ; p<0.05)$. The equation is as follows:

$$
Y_{0}=36.271-0.178 \text { Age }-0.068 \text { Gender }+0.106 \text { Projects }
$$

Table 8. Factorial weights in the cognitive attitudes regression model.

\begin{tabular}{cccccc}
\hline & Standardized Coefficients $\boldsymbol{\beta}$ & $\boldsymbol{t}$ & Sig. & Tolerance & VIF \\
\hline Constant & 36.271 & 42.324 & 0.001 & & \\
Age & -0.178 & -5.243 & 0.001 & 0.985 & 1.015 \\
N Projects & 0.106 & 3.128 & 0.002 & 0.991 & 1.009 \\
N Stays & 0.013 & 0.374 & 0.709 & 0.943 & 1.060 \\
Experience & -0.005 & -0.090 & 0.929 & 0.318 & 3.149 \\
N Postgraduate & 0.006 & 0.158 & 0.875 & 0.916 & 1.092 \\
Gender & -0.068 & -2.004 & 0.045 & 0.991 & 1.009 \\
Sexennium & 0.027 & 0.724 & 0.469 & 0.792 & 1.262 \\
PhD & 0.017 & 0.480 & 0.632 & 0.861 & 1.162 \\
Teaching & -0.054 & -1.605 & 0.109 & 0.987 & 1.013 \\
University & -0.021 & -0.615 & 0.539 & 0.972 & 1.029 \\
\hline
\end{tabular}

Source: Own elaboration. 


\subsubsection{Regression: Behavioral Attitudes towards ICT in Teaching and Research}

Table 9 shows that the assumptions of normality of the residues were accepted, just as the statistician Durbin-Watson indicated independence of the residues (D.W. $=1.88$ ).

This model about behavioral attitudes was significant, $F(3,853)=18.280 ; p<0.05$, adjusted $\mathrm{R}^{2}$ $=0.057$. Only three predictors were significant in the model: Age $(t=-3.323 ; p<0.05)$, number of research/innovation projects $(t=5.237 ; p<0.05)$, and teaching $(t=-4.326 ; p<0.05)$. The regression line was the following:

$$
Y_{0}=32.584-0.1111 \text { Age }+0.175 \text { Projects }-0.144 \text { Teaching }
$$

Table 9. Factorial weights in the behavioral attitudes regression model.

\begin{tabular}{cccccc}
\hline & Standardized Coefficients $\boldsymbol{\beta}$ & $\boldsymbol{t}$ & Sig. & Tolerance & VIF \\
\hline Constant & 32.584 & 26.943 & 0.001 & & \\
Age & -0.111 & -3.323 & 0.001 & 0.985 & 1.015 \\
N Projects & 0.175 & 5.237 & 0.001 & 0.990 & 1.010 \\
N Stays & 0.037 & 1.082 & 0.279 & 0.943 & 1.061 \\
Experience & 0.043 & 0.730 & 0.466 & 0.320 & 3.128 \\
N Postgraduate & 0.046 & 1.325 & 0.186 & 0.910 & 1.099 \\
Gender & -0.012 & -0.363 & 0.717 & 0.984 & 1.016 \\
Sexennium & 0.058 & 1.539 & 0.124 & 0.785 & 1.275 \\
PhD & -0.023 & -0.649 & 0.516 & 0.862 & 1.160 \\
Teaching & -0.144 & -4.326 & 0.001 & 0.991 & 1.009 \\
University & -0.007 & -0.180 & 0.857 & 0.747 & 1.339 \\
\hline
\end{tabular}

\section{Discussion}

The results obtained in the present work show that, despite having a great responsibility to train students in digital technologies based on their continual growth, university teaching staff have an average attitude towards the use of ICT. This attitude conditions, to a large extent, the use that they make of ICT in the teaching-learning process since the more positive the attitude towards the use of $\mathrm{ICT}$, the more efficient will be the use such technology in their teaching, according to Hue and $\mathrm{Ab}$ Jalil [14], Alshammari et al. [18], Prior et al. [17] and Yang and Kwok [19]. This, therefore, corroborates the statement made by Biesta [2] and Villegas et al. [3] that it is necessary for university teaching staff to have greater training in digital competence.

After conducting a more detailed analysis of attitudes, focusing interest on the three dimensions established by Ostrom [29], Norman [30], Breckler [31] and Maio et al. [32], the teachers participating in the study were found to have a higher level of self-perception in relation to cognitive attitudes. However, it should be noted that the total score of this dimension was average. These results are in accordance with those obtained by Judi et al. [47] since, according to their study, university teachers had a positive attitude in the cognitive dimension more so than in any other dimensions analysed.

In the present work, the self-perceived assessment of the participants in relation to the affective dimension is inferior to the cognitive dimension of attitude. However, the affective dimension is more valued than the behavioural dimension. After reviewing different research that focuses on analysing attitudes towards ICT in the three dimensions and comparing to the results of this study, it is apparent that there are no concordant results. In each of them, the score or assessment of the attitude (whether cognitive, behavioural or affective) is different. For example, in the studies conducted by Abdullah et al. [48] and Judi et al. [47], affective attitudes had lower scores than cognitive and behavioural attitudes, while in the present study, affective attitudes obtained a score between these two dimensions. On the other hand, for Jegede et al. [12] and Wahyuni [49] the affective dimension had the highest valuation. All this confirms the statement made by Ankiewicz [28] that it is not possible to establish unitary scores 
towards attitude because it influences not only the dimensions analysed in the present work, but also a multitude of personal and professional variables.

When carrying out the inferential analysis of the variables investigated, it can be seen that the predictors of the total attitude towards the use of ICT are age, participation in projects, gender and type of teaching, according to order of appearance in the equation. Part of these results coincides with those obtained by Onasanya et al. [50] since in their study gender did have an influence. Nonetheless, it should be noted that, according to these researchers, work experience was also an influential variable, while in this research, work experience was not a predictor variable. Alshammari et al. [18] made a similar finding since in their research the main predictors of attitudes towards ICT were age and work experience, while age was an influential variable in the present study.

When trying to predict the conditioning variables of attitude by dimensions, different results are also obtained: Age is a variable that influences the three dimensions analysed; gender only influences the affective and cognitive dimension; participation in research projects influences the cognitive and behavioural dimension, while teaching in a face-to-face or online university only influences the behavioural dimension.

\section{Conclusions}

After carrying out the study, it can be seen that university teaching staff have an average level of self-perception regarding attitudes, which evidences the need to motivate university teachers to increase their attitude towards ICT use. This is because having an average attitude of use conditions the teaching position towards the integration of ICT in the teaching-learning processes, and therefore hinders university innovation. Thus, it is necessary to make profitable the benefits of ICT and offer a high quality of teaching that is adapted to the formative demands of the students and the present social conditions.

The results show that teachers are aware of the importance of the use of ICT in all areas of university life, but despite this it is still underused because not all of them use ICT regularly in their teaching. It would be advisable, therefore, for the university itself to promote more the incorporation of ICT in a transversal manner and for university teachers to receive more practical ICT training. This is because attitudes have a decisive influence on decisions regarding whether to use ICT or not. Therefore, it is the political responsibility of each Spanish university to increase resources, implement training courses and encourage teachers, and for this it is required that these institutions allocate not only resources to performing good ICT practices, but also to make available for teachers the time needed to achieve that purpose.

One must also remember that attitudes are subjective assessments. Therefore, a limitation of the present study was the fact that it was not complemented with qualitative research, for example, conducting in-depth interviews with the teachers to find out their attitudes and thus to contrast the quantitative and qualitative data.

Regarding future lines of research, this work could be continued by taking into account the opinion of students, designing an assessment tool for students to assess the attitudes of university teachers and triangulating the information obtained through different research agents.

Author Contributions: Conceptualization, F.D.G.-G. and M.J.M.-F.; methodology, F.D.G.-G.; validation, F.D.G.-G.; formal analysis, F.D.G.-G.; investigation, F.D.G.-G. and M.J.M.-F.; resources, F.D.G.-G. and M.J.M.-F.; data curation, F.D.G.-G. and M.J.M.-F.; writing—original draft preparation, F.D.G.-G. and M.J.M.-F.; writing—review and editing, F.D.G.-G. and M.J.M.-F.; visualization, F.D.G.-G. and M.J.M.-F.; supervision, F.D.G.-G. and M.J.M.-F.; project administration, F.D.G.-G. and M.J.M.-F.; funding acquisition, F.D.G.-G. and M.J.M.-F. All authors have read and agreed to the published version of the manuscript.

Funding: This research received no external funding.

Conflicts of Interest: The authors declare no conflicts of interest. 


\section{References}

1. Wang, X.; Dostál, J. An analysis of the integration of ICT in education from the perspective of teachers' attitudes. EDULEARN 2017, 17, 8156-8162.

2. Biesta, G. The future of teacher education: Evidence, competence or wisdom. In A Companion to Research in Teacher Education; Springer: Berlin/Heidelberg, Germany, 2017; pp. 435-453. [CrossRef]

3. Villegas, A.M.; SaizdeLaMora, K.; Martin, A.D.; Mills, T. Preparing future mainstream teachers to teach English language learners: A review of the empirical literature. In The Educational Forum; Routledge: London, UK, 2018; Volume 82, pp. 138-155. [CrossRef]

4. Guillén-Gámez, F.D.; Álvarez-García, F.J.; Rodríguez, I.M. Digital tablets in the music classroom: A study about the academic performance of students in the BYOD context. J. Music Technol. Educ. 2018, 11, 171-182. [CrossRef]

5. Becker, S.A.; Cummins, M.; Davis, A.; Freeman, A.; Hall, C.G.; Ananthanarayanan, V. NMC Horizon Report: 2017 Higher Education Edition; The New Media Consortium: Austin, TX, USA, 2017.

6. Dostál, J.; Wang, X.; Nuangchalerm, P. Experiments in Education Supported by Computer Use: Teachers' Attitudes towards Computers. In Proceedings of the CSEDU, Porto, Portugal, 2017; pp. 248-254.

7. Hills, P.J. The Self-Teaching Process in Higher Education; Routledge: New York, NY, USA, 2018.

8. Mikropoulos, T.A. Research on E-Learning and ICT in Education: Technological, Pedagogical and Instructional Perspectives; Springer: Berlin/Heidelberg, Germany, 2018.

9. Nielsen, B.L.; Brandt, H. Learning before technology: What is needed, pedagogically, for students to benefit from new technology? Augmented reality as an example. In Xviii Ioste Symposium: Future Educational Challenges from Science \& Technology Perspectives; Malmo, Sweden, 2018; pp. 1-12.

10. Alemayehu, G.; Natarajan, M. Impact of ICT facility on student's academic performance in Jimma University, EthiopiaInternational. J. Inf. Dissem. Technol. 2018, 8, 136-142. [CrossRef]

11. Guillén-Gámez, F.D.; Mayorga-Fernández, M.J.; Bravo-Agapito, J.; Escribano-Ortiz, D. Analysis of Teachers' Pedagogical Digital Competence: Identification of Factors Predicting Their Acquisition. Technol. Knowl. Learn. 2020, 1-18. [CrossRef]

12. Jegede, P.O.; Dibu-Ojerinde, O.O.; Ilori, M.O. Relationships between ICT competence and attitude among some Nigerian tertiary institution lecturers. Educ. Res. Rev. 2007, 2, 172-175.

13. Bamigboye, O.B.; Bankole, O.M.; Ajiboye, B.A.; George, A.E. Teachers' attitude and competence towards the use of ICT resources: A case study of university of agriculture lecturers, Abeokuta Ogun State, Nigeria. Inf. Manag. 2013, 13, 10-15.

14. Hue, L.T.; Ab Jalil, H. Attitudes towards ICT Integration into Curriculum and Usage among University Lecturers in Vietnam. Int. J. Instr. 2013, 6, 53-66.

15. Kpolovie, P.J.; Awusaku, O.K. ICT adoption attitude of lecturers. Eur. J. Comput. Sci. Inf. Technol. 2016, 4, 9-57.

16. Nilsson, A. Attitudes towards, Expectations of, and Competence Regarding ICT and Digital Learning Tools: A Quantitative Study among Swedish EFL Teachers in Secondary/Upper Secondary School. Bachelor's Thesis, Linnaeus University, Faculty of Arts and Humanities, Department of Languages, Småland, Sweden, 8 June 2018; pp. 1-39.

17. Prior, D.D.; Mazanov, J.; Meacheam, D.; Heaslip, G.; Hanson, J. Attitude, digital literacy and self efficacy: Flow-on effects for online learning behaviour. Internet High. Educ. 2016, 29, 91-97. [CrossRef]

18. Alshammari, R.; Reyes, V.C., Jr.; Parkes, M. Faculty Attitudes towards the Use of Mobile Devices in EFL Teaching in a Saudi Arabian Setting. In Mobile Learning Futures—Sustaining Quality Research and Practice in Mobile Learning; Sydney, Australia, 2016; pp. 16-24.

19. Yang, S.; Kwok, D. A study of students' attitudes towards using ICT in a social constructivist environment. Australas. J. Educ. Technol. 2017, 33, 50-63.

20. Semerci, A.; Aydin, M.K. Examining High School Teachers' Attitudes towards ICT Use in Education. Int. J. Progress. Educ. 2018, 14, 93-105. [CrossRef]

21. Kumar, P.G.; Ratnakar, R. A scale to measure farmers' attitude towards ICT-based extension services. Indian Res. J. Ext. Educ. 2016, 11, 109-112.

22. Cai, Z.; Fan, X.; Du, J. Gender and attitudes toward technology use: A meta-analysis. Comput. Educ. 2017, 105, 1-13. [CrossRef] 
23. Spanos, D.; Sofos, A. The views and attitudes of students participating in a one-to-one laptop initiative in Greece. Educ. Inf. Technol. 2015, 20, 519-535. [CrossRef]

24. Yang, H.; Yoo, Y. It's all about attitude: Revisiting the technology acceptance model. Decis. Support Syst. 2004, 38, 19-31. [CrossRef]

25. Tejedor, F.J.T.; Muñoz-Repiso, A.G.-V.; San Segundo, S.P. Medida de actitudes del profesorado universitario hacia la integración de las TIC. Comun. Rev. Científica Iberoam. Comun. Y Educ. 2009, 115-124. [CrossRef]

26. Ordóñez, X.; Romero, S. Scale of Attitudes Towards ICT (SATICT): Factor Structure and Factorial Invariance in Distance University Students. In Proceedings of the CARMA 2016: 1st International Conference on Advanced Research Methods in Analytics, Valencia, Spain, 6-7 July 2016; pp. 159-166.

27. Rosen, L.; Carrier, L.M.; Miller, A.; Rokkum, J.; Ruiz, A. Sleeping with technology: Cognitive, affective, and technology usage predictors of sleep problems among college students. Sleep Health 2016, 2, 49-56. [CrossRef]

28. Ankiewicz, P. Perceptions and attitudes of pupils toward technology. Handb. Technol. Educ. 2019, 29, 581-595.

29. Ostrom, T.M. The relationship between the affective, behavioral, and cognitive components of attitude. J. Exp. Soc. Psychol. 1969, 5, 12-30. [CrossRef]

30. Norman, R. Affective-cognitive consistency, attitudes, conformity, and behaviour. J. Personal. Soc. Psychol. 1975, 32, 83. [CrossRef]

31. Breckler, S.J. Empirical validation of affect, behavior, and cognition as distinct components of attitude. J. Personal. Soc. Psychol. 1984, 47, 1191. [CrossRef]

32. Maio, G.R.; Haddock, G.; Verplanken, B. The Psychology of Attitudes and Attitude Change; Sage Publications Limited: Chennay, India, 2018.

33. Liaw, S.S. Considerations for developing constructivist web-based learning. Int. J. Instr. Media 2004, 31, 309-319.

34. Liaw, S.S.; Huang, H.M. Developing a collaborative e-learning system based on users' perceptions. In Proceedings of the International Conference on Computer Supported Cooperative Work in Design, Nanjing, China, 3-5 May 2006; Springer: Berlin/Heidelberg, Germany, 2006; pp. 751-759. [CrossRef]

35. Abdullah, N.A.; Abidin, M.J.Z.; Luan, W.S.; Majid, O.; Atan, H. The attitude and motivation of English language teachers towards the use of computers. Malays. Online J. Instr. Technol. 2006, 3, 57-67.

36. García, F.J.; García, J. Educational hypermedia resources facilitator. Comput. Educ. 2005, 44, 301-325. [CrossRef]

37. Peng, C.A.; Daud, S.M. Relationship between Special Education (hearing impairment) teachers' Technological Pedagogical Content Knowledge (TPACK) and their attitudes toward ICT integration. In Proceedings of the International Conference on Special Education in Southeast Asia Region 6th Series, Region 6, Asia, 2016; pp. 1-3.

38. Siragusa, L.; Dixon, K.C. Planned behaviour: Student attitudes towards the use of ICT interactions in higher education. Hello! Where Are You in the Landscape of Educational Technology? Proc. Ascilite Melb. 2008, 2008, 942-953.

39. Şahin-Kizil, A. EFL teachers attitudes towards information and communication technologies (ICT). In Proceedings of the 5th International Computer \& Instructional Technologies Symposium, Elazığ Turkey, 22-24 September 2011.

40. Zhang, P.; Aikman, S.N.; Sun, H. Two types of attitudes in ICT acceptance and useIntl. J. Hum. Comput. Interact. 2008, 24, 628-648. [CrossRef]

41. Shah, P.M.; Empungan, J.L. ESL teachers' attitudes towards using ICT in literature lessons. Int. J. Engl. Lang. Educ. 2015, 3, 201-218. [CrossRef]

42. González-Sanmamed, M.; Sangrà, A.; Muñoz-Carril, P.-C. We can, we know how. But do we want to? Teaching attitudes towards ICT based on the level of technology integration in schools. Technol. Pedagog. Educ. 2017, 26, 633-647. [CrossRef]

43. Ursavas, Ö.F.; Bahçekapıl1, T.; Camadan, F.; İslamoğlu, H. Teachers' behavioural intention to use ICT: A structural equation model approach. In Proceedings of the Society for Information Technology \& Teacher Education International Conference, Las Vegas, NV, USA, 2 March 2015; Association for the Advancement of Computing in Education (AACE): Chesapeake, VA, USA, 2015; pp. 2875-2880.

44. Ankiewicz, P.; Van Rensburg, S.; Myburgh, C. Assessing the attitudinal technology profile of South African learners: A pilot study. Int. J. Technol. Des. Educ. 2001, 11, 93-109. [CrossRef] 
45. Shaft, T.M.; Sharfman, M.P.; Wu, W.W. Reliability assessment of the attitude towards computers instrument (ATCI). Comput. Hum. Behav. 2004, 20, 661-689. [CrossRef]

46. Bakr, S.M. Attitudes of Egyptian teachers towards computers. Contemp. Educ. Technol. 2011, 2, 308-318. [CrossRef]

47. Judi, H.M.; Mohamed, H.; Noor, S.F.M. Perceived attitude of teachers in rural areas towards information and communication technology. Soc. Sci. (Pak.) 2016, 11, 5590-5596. [CrossRef]

48. Abdullah, Z.D.; Ziden, B.A.; Chi Aman, R. Students' Attitudes towards Information Technology and the Relationship with Their Academic Achievement. Contemp. Educ. Technol. 2015, 6, 338-354. [CrossRef]

49. Wahyuni, S. CAC Model to Evaluate Teachers' Attitudes towards Technology Use in Their EFL Classrooms. Lang. Circ. J. Lang. Lit. 2018, 13. [CrossRef]

50. Onasanya, S.A.; Shehu, R.A.; Oduwaiye, R.O.; Shehu, L.A. Higher institutions lecturers' attitude towards integration of ICT into teaching and research in Nigeria. Res. J. Inf. Technol. 2010, 2, 1-10. [CrossRef]

51. Olafare, F.O.; Adeyanju, L.O.; Fakorede, S.O.A. Colleges of Education Lecturers Attitude towards the Use of Information and Communication Technology in Nigeria. Malays. Online J. Educ. Sci. 2018, 5, 1-12.

52. Kerlinger, F.N.; Lee, H.B.; Pineda, L.E.; Mora Magaña, I. Investigación del Comportamiento; McGraw Hill: Mexico City, Mexico, 2002.

53. Ministerio de Ciencia, Innovación Y Universidades. Datos y Cifras del Sistema Universitario Español. 2019. Available online: http://www.educacionyfp.gob.es/dam/jcr:2af709c9-9532-414e-9bad-c390d32998d4/datos-ycifras-sue-2018-19.pdf (accessed on 12 October 2019).

54. Romero, M.S.; Guillén-Gámez, F.D.; Ordoñez, C.X.; Mayorga-Fernández, M.J. Factorial development and structure of an attitude instrument towards the use of technology for teaching and research in university teachers. Tecnol. Cienc. Y Educ. 2020, 16, 1-27, in press.

55. Chen, Y. Spatial autocorrelation approaches to testing residuals from least squares regression. PLoS ONE 2016, 11, e0146865. [CrossRef]

56. Chan, Y.H. Biostatistics 201: Linear regression analysis. Singap. Med J. 2004, 45, 55-61.

57. Ghani, I.M.M.; Ahmad, S. Stepwise multiple regression method to forecast fish landing. Procedia Soc. Behav. Sci. 2010, 8, 549-554. [CrossRef] 